\title{
PENCEGAHAN BURNOUT PADA KEGIATAN PEMBELAJARAN DARING DI LINGKUNGAN PELAJAR
}

\author{
Anastasia Ratnawati Biromo ${ }^{1}$, Vera Ariani ${ }^{2}$,Muhammad Rizal Permana ${ }^{3}$ \\ ${ }^{1}$ Bagian Ilmu Kesehatan Jiwa, Fakultas Kedokteran, Universitas Tarumanagara Jakarta \\ Email: anastasia.ratnawati@gmail.com \\ ${ }^{2}$ Fakultas Kedokteran, Universitas Tarumanagara Jakarta \\ Email: vera.405180090@stu.untar.ac.id \\ ${ }^{3}$ Fakultas Kedokteran, Universitas Tarumanagara Jakarta \\ Email: permanarizal093@gmail.com
}

\begin{abstract}
Online learning methods still confuse students into being passive, less creative, and more productive in their academic saturation. Student burnout conditions need to be assessed and addressed so that online learning can be accepted by students without causing fatigue, incompetence, or reducing the essence of discouraging students in learning. Lack of knowledge and information about burnout in students in Indonesia, burnout in the world of education has not received much attention. Counseling activities with a soul-healthy theme learn online to add insight into extension participants about burnout and prevent burnout. There was an increase in the knowledge of counseling participants about healthy online learning by $13.8 \%$ then counseling participants increased insights related to burnout, how to overcome it and healthy souls during online learning. Counseling about healthy souls during online learning is a form of increasing insight into burnout and how to overcome it, this activity was attended by 31 participants and implemented well on November 7, 2021. It is necessary to do counseling activities with burnout material continuously because burnout cases in the academic field must occur a lot among students.
\end{abstract}

Keywords: burnout, soul healthy, online learning

\begin{abstract}
ABSTRAK
Metode pembelajaran online masih membingungkan siswa menjadi pasif, kurang kreatif, dan lebih produktif dalam kejenuhan akademiknya. Kondisi burnout siswa perlu dinilai dan disikapi agar pembelajaran online dapat diterima oleh siswa tanpa menimbulkan kelelahan, ketidakmampuan, atau mengurangi esensi mengecilkan hati siswa dalam belajar. Kurangnya pengetahuan dan informasi tentang burnout pada siswa di Indonesia, burnout dalam dunia pendidikan belum banyak mendapat perhatian. Kegiatan penyuluhan dengan tema sehat jiwa belajar daring untuk menambah wawasan peserta penyuluhan tentang burnout dan mencegah burnout. Terjadi peningkatan pengetahuan peserta penyuluhan tentang sehat jiwa belajar daring sebesar $13.8 \%$ maka peserta penyuluhan bertambah wawasan terkait burnout, cara mengatasinya serta sehat jiwa selama pembelajaran daring. Penyuluhan tentang sehat jiwa selama pembelajaran daring adalah suatu bentuk penambahan wawasan tentang burnout serta cara mengatasinya, kegiatan ini dihadiri 31 peserta dan dilaksanakan dengan baik pada tanggal 7 November 2021. Perlu dilakukan kegiatan penyuluhan dengan materi burnout secara berkesinambungan karena kasus burnout dalam bidang akademis pasti banyak terjadi dikalangan mahasiswa.
\end{abstract}

Kata kunci : burnout, sehat jiwa, pembelajaran daring

\section{PENDAHULUAN}

Pemerintah mengeluarkan peraturan dalam proses penyelenggaraan sistem pendidikan, awalnya dilakukan secara langsung, dan pada masa pandemi sistem pembelajaran dilaksanakan secara online (Firman \& Rahayu, 2020). Sistem pembelajaran dari rumah secara daring juga diterapkan di pendidikan. Sistem pembelajaran dari rumah telah mengubah cara belajar bagi para pelajar hingga mahasiswa (Kes et al., 2020; Trisnadewi \& Muliani, 2020). Pelajar atau mahasiswa dengan metode pembelajaran secara daring bertujuan agar dapat lebih mandiri, bertanggung jawab terhadap tugas, memberikan motivasi serta semangat yang tinggi sehingga manfaat yang didapatkan mahasiswa lebih otonomi dalam belajar (learning autuonomy) dan mempersiapkan 
diri menghadapi perkembangan teknologi (Gusty et al., 2020; Hamdan et al., 2021; Pangondian et al., 2019; Syarifudin, 2020; Thompson, 2013).

Metode pembelajaran online merupakan model pembelajaran inovatif multi mata pelajaran/kursus yang diterapkan di beberapa SMA danperguruan tinggi sebelum adanya pandemi. Reaksi siswa terhadap penggunaan metode online pra pandemi tidak menjadi masalah bagi siswa, namun siswa antusias mengikuti pembelajaran karena pembelajaran online yang mereka alami merupakan pengalaman belajar yang baru. (Anggrawan, 2019). Pada saat pandemi, metode pembelajaran daring memberikan hasil yang berbeda yaitu motivasi belajar menurun, merasa bosan diikuti perasaan jenuh yang kronis, merasakan kelelahan baik fisik maupun mental sehingga kondisi ini membuat pelajar/mahasiswa mengalami stress berkepanjangan (FernandezCastillo, 2021).

Beberapa penelitian menunjukkan bahwa penyebab penurunan motivasi belajar, kelelahan fisik dan mental disebabkan oleh gangguan yang terjadi selama proses pembelajaran online seperti kendala bagi siswa ketika akses internet yang buruk sehingga informasi dan transfer pengetahuan yang tidak jelas dan susah dipahami serta mengganggu proses pembelajaran, interaksi staf pendidik dengan pelajar/mahasiswa ataupun sesama pelajar/mahasiswa, serta lingkungan belajar tidak berjalan dengan baik. (Hikmat dkk, 2020; Jariyah, 2020; Nurkholis, 2020; Pawicara , 2020). Mahasiswa yang terus mengalami hambatan ini selama proses perkuliahan pandemi mempengaruhi motivasi mereka untuk berprestasi, dan stres yang terusmenerus memicu burnout pada proses pengembangan akademik (Fernandez, 2021).

Kondisi seseorang burnout maka timbul lelah secara fisik, mental, emosional diikuti dengan sinisme, penghindaran lingkungan sekitar dan harga diri yang buruk (Gold, 1993; Maslach, 2003). Kondisi burnout yang terjadi pada mahasiswa dipicu tuntutan akademik berlebihan dan terus menerus, maka kinerja akademik mengalami kemunduran, memicu stress sehingga kondisi mental menjadi terbebani. (Aguayo,2019; Christiana, 2020; Gungor, 2019). Burn Out yang terjadi di kalangan mahasiswa memberikan dampak kehilangan minat atau penghindaran dari lingkungan belajar, ketidakberdayaan dan keputusasaan, siapa pun dapat mengalami burnout, dan selama pandemi ini, burnout akademik berdampak signifikan pada mahasiswa. (Aguayo, 2019; Andi, 2020; Christiana, 2020; Gungor, 2019; McCormack, 2013).

Pembelajaran daring memiliki dampak terhadap mahasiswa sehingga pelajar/mahasiwa merasakan proses pembelajaran daring kurang bermanfaat, timbul perasaan lelah dan mengalami stress, akibatnya pelajar/mahasiswa mengalami burnout akademik. Kondisi burnout akademik dikalangan pelajar/mahasiwa perlu dievaluasi dan ditangani Di Indonesia perhatian terhadap masalah burnout akademi masih kurang perhatian karena kurangnya pengetahuan serta informasi tentang burnout akademik dikalangan pelajar/mahasiswa.

\section{METODE PELAKSANAAN PKM}

Berdasarkan kondisi diatas maka kami melakukan kegiatan penyuluhan terkait burnout akademik dikalangan mahasiswa. Penyuluhan yang tim pengabdian lakukan dapat meningkatkan wawasan serta kesadaran untuk mencegah burnout karena mahasiswa yang mengalami burnout. Kegiatan penyuluhan interaktif membuat peserta dapat berinteraksi langsung dan diharapkan dapat meningkatkan pengetahuan dan mengupayakan diri dalam usaha pencegahan terjadinya burnout.

Dengan kegiatan berbentuk penyuluhan interaktif diharapkan dapat meningkatkan pengetahuan dan motivasi burnout. Tim pengabdian menggunakan metode untuk memaparkan burnout melalui penyuluhan, pretest, post test dan tanya jawab. Sebelumnya dilakukan pretest terkait materi yang dipaparkan setelah itu penyuluhan dan tanya jawab. Setelah penyuluhan maka dilakukan posttest. 


\section{HASIL DAN PEMBAHASAN}

Rapat persiapan pertama telah dilaksanakan pada tanggal 15 Oktober 2021. Dalam rapat tersebut, tim membahas mengenai rencana waktu pelaksanaan, persiapan pretes dan postes hingga games yang akan dilakukan biar peserta tidak merasa bosan, hanya mendengar penyuluhan saja. Tim kemudian menentukan waktu pelaksanaan kegiatan bakti kesehatan akan dilaksanakan pada tanggal 7 November 2021, mulai pukul 13.00-15.00 WIB dengan mempertimbangkan calon peserta tidak ada kegiatan pembelajaran di hari tersebut. Tim juga hasil rapat disepakati bahwa pelaksanaan kegiatan bakti kesehatan akan dilaksanakan pada merencanakan akan melakukan rapat persiapan kedua padata tanggl 2 November 2021 sebagai persiapan akhir sebelum pelaksanaan kegiatan bakti kesehatan. Kegiatan bakti kesehatan dilaksanakan pada tanggal 07 November 2021 secara daring dengan menggunakan aplikasi zoom meeting, dihadiri Kegiatan dimulai pada pukul 13.00 WIB diawali dengan pembukaan dan peserta diminta untuk mengisi pretes terlebih dahulu, setelahnya kegiatan edukasi dimulai dengan topik mengenai kiat kiat menghadapi burnout dipaparkan oleh dr Anastasia, SpKJ. Susunan acara kegiatan dapat dilihat pada tabel 1 :

Tabel 1 . Susunan acara kegiatan

\begin{tabular}{lll} 
Waktu & Topik & Pembicara \\
\hline $12.15-12.40$ & Registrasi & Panitia \\
\hline $12.40-12.45$ & Pembukaan & Panitia \\
\hline $12.45-13.00$ & Pre Tes & Panitia \\
\hline $13.00-13.30$ & Games & Panitia \\
\hline $13.30-13.45$ & Games & Panitia \\
\hline $13.45-14.15$ & Cara mengatasi burnout & Tim Bakti Kesehatan dr. Anastasia \\
\hline $14.15-14.30$ & Tanya Jawab & \\
\hline $14.30-15.00$ & Penutupan dan Postes & \\
\hline
\end{tabular}

Kegiatan penyuluhan terkait cara mengatasi burnout agar sehat jiwa selama pembelajaran daring dapat dilihat pada gambar 1. Materi cara mengatasi burnout yang dipaparkan dr Anastasia Ratnawati Biromo, SpKJ mencakup untuk sehat jiwa selama pembelajaran daring, kendala dalam belajar daring serta cara mengatasinya. Kegiatan penyuluhan yang dilakukan secara interaktif membuat peserta dapat berinteraksi langsung dan diharapkan dapat meningkatkan pengetahuan dan mengupayakan diri dalam usaha pencegahan terjadinya burnout. Program penyuluhan sehat jiwa selama pembelajaran daring dapat meningkatkan pengetahuan dan kesadaran terkait burnout dan memberikan kesadaran untuk mencegah burnout karena mahasiswa yang mengalami burnout cenderung pasif dan mengikuti pola formalistik dalam penyelesaian proses belajarnya, pelajar/mahasiswa kurang mampu memecahkan suatu masalah dengan mengaplikasikan materi kuliah yang telah dipelajari. 

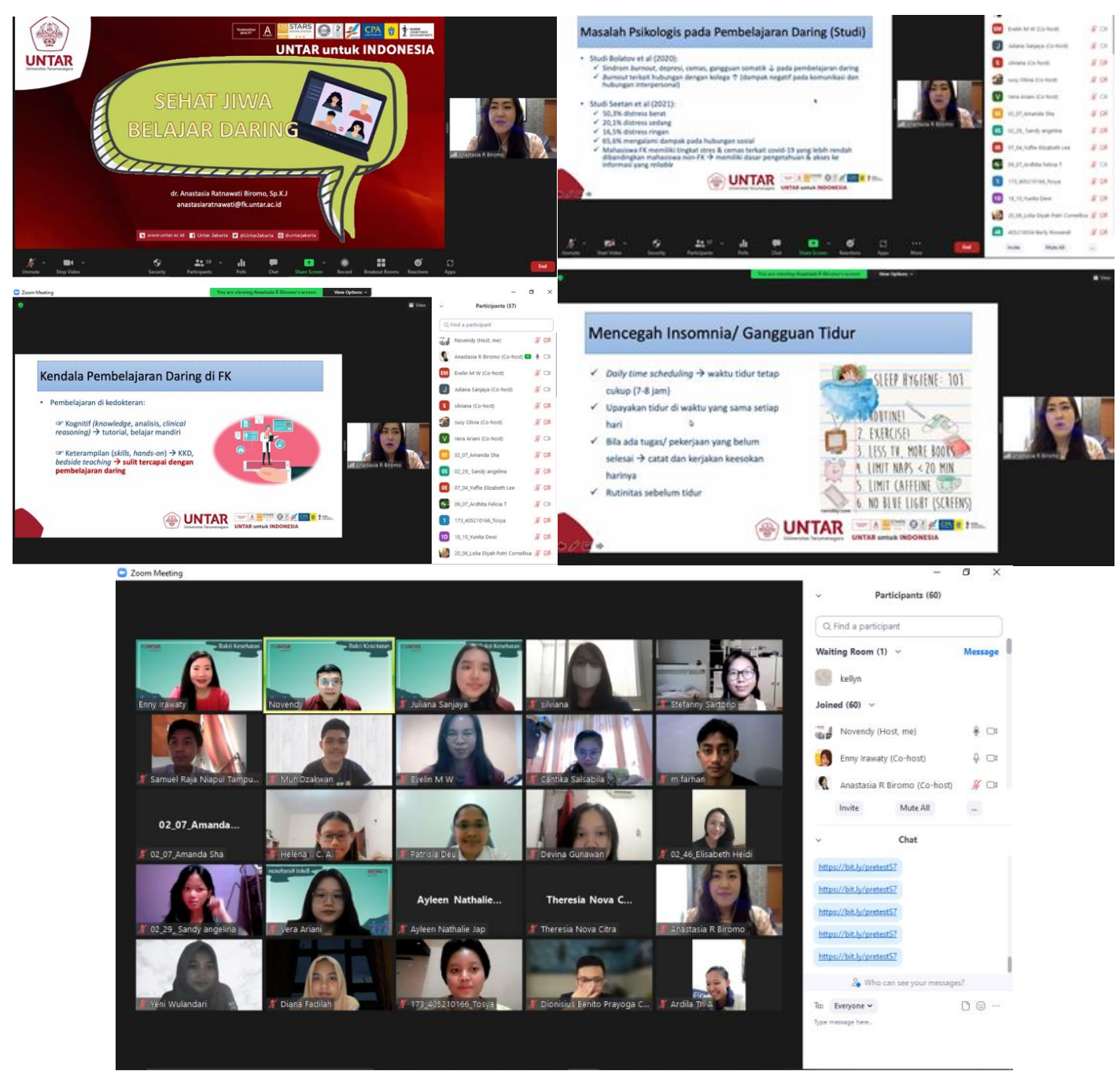

Gambar 1. Kegiatan penyuluhan

Kegiatan penyuluhan tentang sehat jiwa belajar daring dihadiri oleh 31 peserta, sebanyak 8 (25.8\%) peserta berjenis kelamin laki-laki dan 23 (74.2\%) peserta berjenis kelamin perempuan, rata-rata usia peserta penyuluhan adalah 18.5 tahun dengan rentang usia antara $17-26$ tahun. Nilai rata-rata pretes yang dilakukan sebelum pemaparan materi adalah 65 , setelah dilakukan penyuluhan mengenai materi burnout maka hasil nilai rata-rata postest adalah 74 , terjadi peningkatan pengetahuan peserta penyuluhan setelah mengikuti kegiatan sebesar $13.8 \%$. Hasil kegiatan dapat dilihat pada gambar 2 . 

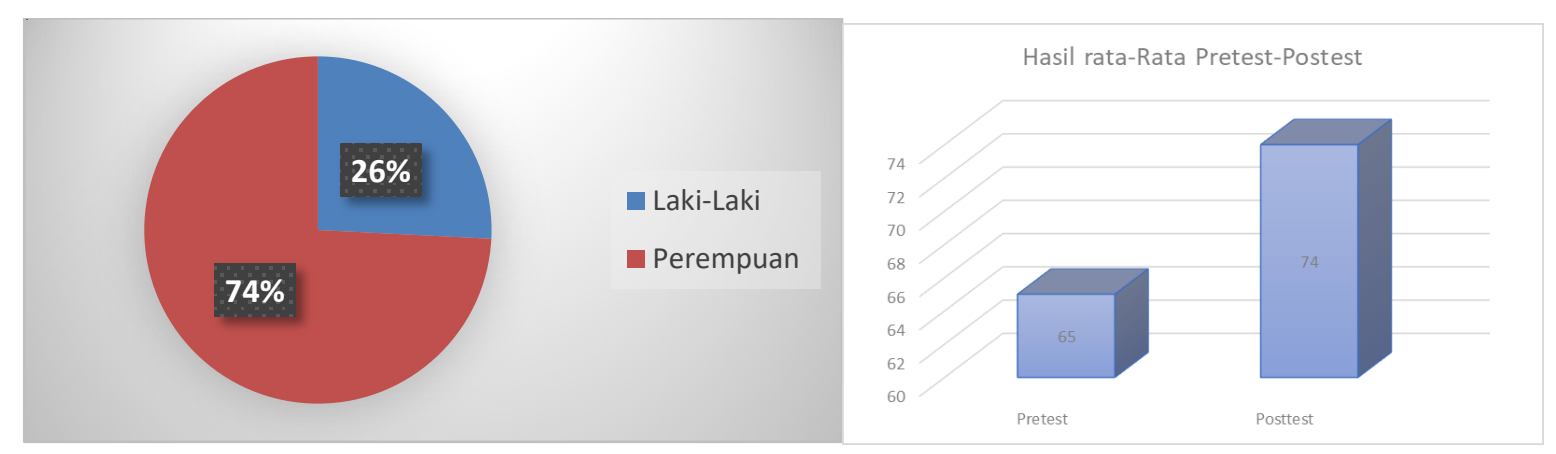

Gambar 2. Hasil kegiatan penyuluhan

\section{KESIMPULAN DAN SARAN}

Terjadi peningkatan pengetahuan peserta penyuluhan tentang sehat jiwa belajar daring sebesar $13.8 \%$ maka peserta penyuluhan bertambah wawasan terkait burnout, cara mengatasinya serta sehat jiwa selama pembelajaran daring. Penyuluhan tentang sehat jiwa selama pembelajaran daring adalah suatu bentuk penambahan wawasan tentang burnout serta cara mengatasinya, kegiatan ini dihadiri 31 peserta dan dilaksanakan dengan baik pada tanggal 7 November 2021. Perlu dilakukan kegiatan penyuluhan dengan materi burnout secara berkesinambungan karena kasus burnout dalam bidang akademis pasti banyak terjadi dikalangan mahasiswa.

\section{Ucapan Terima Kasih (Acknowledgement)}

Penulis PKM mengucapkan terima kasih kepada Rektor Universitas Tarumanagara beserta jajaran, LLPM Universitas Tarumanagara atas pendanaan sehingga kegiatan pengabdian kepada masyarakat dapat terlaksana, Pimpinan Fakultas Kedokteran Universitas Tarumanagara beserta jajaran atas dukungannya dalam pelaksanaan kegiatan PKM ini. Terima kasih kepada peserta PKM atas dukungan dan partisipasinya dalam kegiatan ini. Terima kasih juga kepada Panitia SENAPENMAS yang memberikan kesempatan sehingga dapat berpatisipasi pada kegiatan SENAPENMAS 2021

\section{REFERENSI}

Anggrawan, A. (2019). Analisis deskriptif hasil belajar pembelajaran tatap muka dan pembelajaran daring menurut gaya belajar mahasiswa. Jurnal MATRIK, 18(2). https://doi.org/10.30812/matrik.v18i2.411

Firman, F, Rahayu, S. (2020). Pembelajaran online di tengah pandemi covid-19. Indonesian Journal of Educational Science (IJES), 2(2), 81-89. https://ojs.unsulbar.ac.id/index.php/ijes/article/view/659

Fernandez-Castillo, A. (2021). State-anxiety and academic burnout regarding university access selective examinations in spain during and after the covid-19 lockdown. Frontier in Psychology, 12. https://doi.org/10.3389/fpsyg.2021.621863

Gold, Y, Roth, R. A. (1993). Teachers managing Volume 08, Nomor 02. (2021). Character : stress and preventing burnout: The professional health solution. Routledge Falmer. https://books.google.co.id/books?id=jX4nAAAAQBAJ\&printsec=frontcover\&dq=Teach ers+managing+stress+and+preventing+burnout: + The+professional+health+solution\&hl $=$ en\&sa=X\&ved=2ahUKEwjhv4TqotLsAhWg63MBHZ30AmIQ6AEwAHoECAQQAg

Gusty, S., Nurmiati, N., Muliana, M., Sulaiman, O. K., Ginantra, N. L. W. S. R., Manuhutu, M. A., Sudarso, A., Leuwol, N. V., Apriza, A, Sahabuddin, A. (2020). Belajar Mandiri: Pembelajaran Daring di Tengah Pandemi Covid-19. Yayasan Kita Menulis. https://jurnal.uns.ac.id/kumara/article/view/44282 
Hamdan, K. M., Al-Bashaireh, A. M., Zahran, Z., Al-Daghestani, A., Samira, A.-H., Shaheen, A. M. (2021). University students' interaction, Internet self-efficacy, self- regulation and satisfaction with online education during pandemic crises of COVID-19 (SARS-CoV-2). International Journal of Educational Management. http://neo.ppj.unp.ac.id/index.php/neo/article/view/567

Jariyah, I. A, Tyastirin, E. (2020). Proses dan kendala pembelajaran biologi di masa pandemi Covid-19: Analisis respon mahasiswa. Jurnal Penelitian dan Pengkajian Ilmu Pendidikan: e-Saintika, 4(2). http://journal-center.litpam.com/index.php/e- Saintika/article/view/224/102

Maslach, C. (2003). Burnout: The cost of caring. ISHK. https://www.worldcat.org/title/burnout-the-cost-of-caring/oclc/52493640

Nurkholis. (2020). Dampak pandemi Novel-Corona Virus Disease (Covid-19) terhadap psikologi dan pendidikan serta kebijakan pemerintah. Jurnal PGSD, 6(1). https://doi.org/10.32534/jps.v6i1.1035

Pangondian, R. A., Santosa, P. I., Nugroho, E. (2019). Faktor-faktor yang mempengaruhi kesuksesan pembelajaran daring dalam revolusi industri 4.0. Seminar Nasional Teknologi Komputer \& Sains (SAINTEKS), 1(1). https://seminar-id.com/prosiding/index.php/sainteks/article/download/122/122

Pawicara, R, Conilie, M. (2020). Analisis pembelajaran daring terhadap kejenuhan belajar mahasiswa tadris biologi IAIN Jember di tengah pandemi Covid-19. ALVEOLI: Jurnal Pendidikan Biologi, 1(1). https://alveoli.iain-jember.ac.id/index.php/alv/article/view/7/4

Syarifudin, A. S. (2020). Impelementasi pembelajaran daring untuk meningkatkan mutu pendidikan sebagai dampak diterapkannya social distancing. Jurnal Pendidikan Bahasa Dan Sastra Indonesia Metalingua, 5(1), 31-34. https://journal.trunojoyo.ac.id/metalingua/article/view/7072/0

Thompson, P. (2013). The digital natives as learners: Technology use patterns and approaches to learning. Computers \& Education, 65, 12-33. https://www.researchgate.net/publication/257171683 The digital natives as learners Technolog y_use_patterns_and_approaches_to_learning

Trisnadewi, K, Muliani, N. M. (2020). Pembelajaran Daring di Masa Pandemi Covid-19. https://kitamenulis.id/2020/06/18/covid-19-perspektif-pendidikan/ 